\title{
The Antibiotic Resistance by Bacteria Forming Biofilm into Water Pipes
}

\author{
*Flores-Encarnación, M. ${ }^{1}$, Hernández-Román, J. ${ }^{1}$, Aguilar-Gutiérrez, G.R. ${ }^{2}$, \\ Cabrera-Maldonado, C. ${ }^{3}$, López-García, A. ${ }^{3}$, Ruíz-Tagle, A. ${ }^{3}$, León-Tello, G. ${ }^{3}$ \\ ${ }^{1}$ Laboratorio de Microbiología Molecular y Celular. Biomedicina. Edif. EMA1-421. Facultad de \\ Medicina, Benemérita Universidad Autónoma de Puebla. Puebla, Puebla. México. \\ ${ }^{2}$ Centro de Investigación sobre Enfermedades Infecciosas. Instituto Nacional de Salud Pública. \\ Cuernavaca, Morelos. México. \\ ${ }^{3}$ Dpto. de Microbiología, Facultad de Ciencias Químicas. Benemérita Universidad Autónoma de \\ Puebla. Puebla, Puebla, México.
}

\begin{abstract}
One of the problems associated to bacterial biofilms is the extraordinary resistance to biocides and antibiotics. The biofilm formation gives advantages to bacteria as the natural protection from the environment and the host defense mechanisms. It has been reported that the bacteria are forming biofilm adhered to the walls of water pipes. The bacterial biofilm formation in the water pipes has been of interest in many countries because are pathogenic microorganisms for what constitutes a threat to public health. The present study aimed to seek the antibiotic resistance by bacteria to form biofilm into water pipes commonly used.
\end{abstract}

Keywords: Antibiotic, Resistance, Water, Piper, Biofilm, Drinking.

\section{INTRODUCTION}

As it is known bacteria form biofilms which are complex communities of bacteria adhered to inert surfaces (for example: glass, stainless steel, plastic) or tissues and organs; they contain an exopolysaccharide matrix, water, proteins, nucleic acid, bacteria and bacterial lysis products (Ceri et al, 1999; Costerton et al., 1995; Costerton, 1999; Decho, 2013; Donlan, 2011). One of the problems associated with bacterial biofilms is the extraordinary resistance to biocides (Anderl et al., 2000; Bridier et al., 2011). The biofilm gives certain advantages to bacteria, for example: the natural protection from the environment, also resistance to the bactericidal action of the antimicrobial; the host defense mechanisms are altered (Flores-Encarnación et al., 2014; Kostakioti1 et al., 2013). Currently it has been reported that the bacteria are forming biofilm adhered to the walls of the water pipes. The presence of biofilm in the water supply system is a threat to public health (FloresEncarnación et al., 2016; Hryniszyn et al., 2015; Knobelsdorf and Mujeriego, 1997; Mahapatra et al., 2015).

The biofilms in the water pipes has been of interest in many countries because are pathogenic microorganisms (Ashbolt, 2015; Chaves-Simões and Simões, 2013; Mahapatra et al., 2015).

\section{MATERIAL AND MethodS}

\subsection{Biological Material}

The Pseudomonas aeruginosa, Escherichia coli, Citrobacter freundii and Klebsiella oxytoca bacteria were used. The bacterial samples were previously isolated and identified from domestic water pipes commonly used at the municipality of Puebla, México (Flores-Encarnación et al., 2016). These bacterial species were selected from the group of 25 previous isolates and because they were the most abundant. As reference E. coli K12 strain was used. In all cases the strains were stored into cryovials at $-40^{\circ} \mathrm{C}$ until analysis.

\subsection{Culture}

The nutrient broth $(3 \mathrm{~g} / \mathrm{L}$ beef extract; $5 \mathrm{~g} / \mathrm{L}$ peptone, $\mathrm{pH}$ 6.8) was used for bacterial culture. For that, a total of $125 \mu \mathrm{L}$ of each bacterial strain was inoculated in $5 \mathrm{~mL}$ of nutrient broth and incubated 
overnight at $37^{\circ} \mathrm{C}$ during 24 hours (preculture). The growth in plate was assayed on nutrient agar plates. Bacteria were inoculated in cross groove on nutrient agar plates and it was incubated at $37^{\circ} \mathrm{C}$ for 24 hours.

\subsection{Biofilm Formation Technique using Microplate}

The quantification of bacterial biofilm production was performed according to the modified method described by Stepanovic et al., (2004). Briefly, a total of $125 \mu \mathrm{L}$ of each bacterial preculture was inoculated in $5 \mathrm{~mL}$ of fresh tryptic soy broth. From each bacterial suspension $1 \times 10^{6}$ cell were used in sterile 96 well plates and they were incubated aerobically in humid chamber at $37^{\circ} \mathrm{C}$ during 96 hours. After the incubation time, it proceeded to delete the contents of plate wells and $250 \mu \mathrm{L}$ of $0.1 \%$ crystal violet was added for 20 minutes, staining the bacteria in the biofilm. Then it proceeded to delete the crystal violet of plate wells and dye excess was deleted washing twice with distilled water. The optical density was read spectrophotometrically at $595 \mathrm{~nm}$. On the other hand, the ability to form bacterial biofilm was tested using the calcofluor white staining. So the bacterial sample was placed on a glass slide and then the sample was stained with $0.02 \%$ calcofluor white. The glass slide was incubated at room temperature for $20 \mathrm{~min}$ in the dark and it was then exposed to UV light. All assays were repeated in quadruplicate.

\subsection{Antimicrobial Susceptibility Testing}

To determine the resistance profile of the isolated bacteria the antibiotic diffusion technique was used. For that, bacterial strains were scattered on nutrient agar plates and discs with antibiotics were used: penicillin (10IU), oxacillin $(1 \mu \mathrm{g})$, tetracycline $(30 \mu \mathrm{g})$, nitrofurantoin $(300 \mu \mathrm{g})$, trimethoprimsulfamethoxazole $(23.75 \mu \mathrm{g} / 1.25 \mu \mathrm{g})$ and amikacin $(30 \mu \mathrm{g})$ (B BBL, Sensi-Disc). The bacterial bacteria was incubated overnight at $37^{\circ} \mathrm{C}$ during 24 hours. After twenty-four hours proceeded to make the measurement of growth inhibition. Then it proceeded to compare the results with the parameters of sensitivity and resistance following the rules of Clinical and Laboratory Standards Institute. The diameter of zone of inhibition of growth was recorded.

\section{RESUltS}

For this study P. aeruginosa, E. coli, C. freundii, K. oxytoca and Klebsiella sp. bacteria were used. This bacteria were recovered from water pipes in common use at the municipality of Puebla, México (work previously reported). As described above, the biofilm formation in vitro of each bacterium isolated was determinated as indicated in Material and Methods. The optical density was read spectrophotometrically at $595 \mathrm{~nm}$. The results obtained are shown in the Fig. 1A. As shown in Fig. 1A, all bacteria isolated from water pipes were able to form biofilm. The measurement of biofilm formation for E. coli, P. aeruginosa and $K$. oxytoca showed similar results, showing an average optical density $(595 \mathrm{~nm})$ to 0.45 . C. freundii showed the highest ability to form biofilm having an optical density $(595 \mathrm{~nm})$ close to 0.6 . Fig.1B shows staining the bacteria forming biofilm in plate wells using $0.1 \%$ crystal violet. On the other hand, to confirm the presence of bacteria forming biofilm, it was performed other staining using calcofluor white. For this, bacterial sample was placed on a glass slide and stained with calcofluor white. The calcofluor white is a fluorescent dye, it binds to exopolysaccharides of biofilm matrix. As shown in Fig. 1C, the extended sample on a glass slide produced fluorescence emission when it exposed to UV light.

On the other hand, to determine the resistance profile to antibiotics by bacteria the plate diffusion technique was used. To remember that the bacteria probed were isolated from water pipes commonly used and bacteria were not from clinical isolates. The antibiotics penicillin, oxacillin, tetracycline, nitrofurantoin, trimethoprim-sulfamethoxazole, and amikacin were used. The bacterial strains was incubated overnight at $37^{\circ} \mathrm{C}$ during 24 hours. The results obtained are shown in the Table 1 . As shown in the Table 1 all bacteria were resistant to penicillin and oxacillin. Majority of the bacteria were found to be resistant to tetracycline $(75 \%)$. All bacteria probed were more susceptible to trimethoprim/sulfamethoxazole $(75 \%)$. All bacteria of this study were sensitive to amikacin. $P$. aeruginosa showed the maximum resistance found to the group of antibiotics probed. Only it was found more susceptible to tetracycline and amikacin (33\%). E. coli was found to be sensitive to trimethoprim/sulfamethoxazole, nitrofurantoin and amikacin $(50 \%)$ and it showed resistance to penicillin, oxacillin and tetracycline (50\%). K. oxytoca and $C$. freundii were found to be more sensitive to tetracycline, trimethoprim/sulfamethoxazole, nitrofurantoin and amikacin (66\%) and they showed resistance to penicillin and oxacillin. 


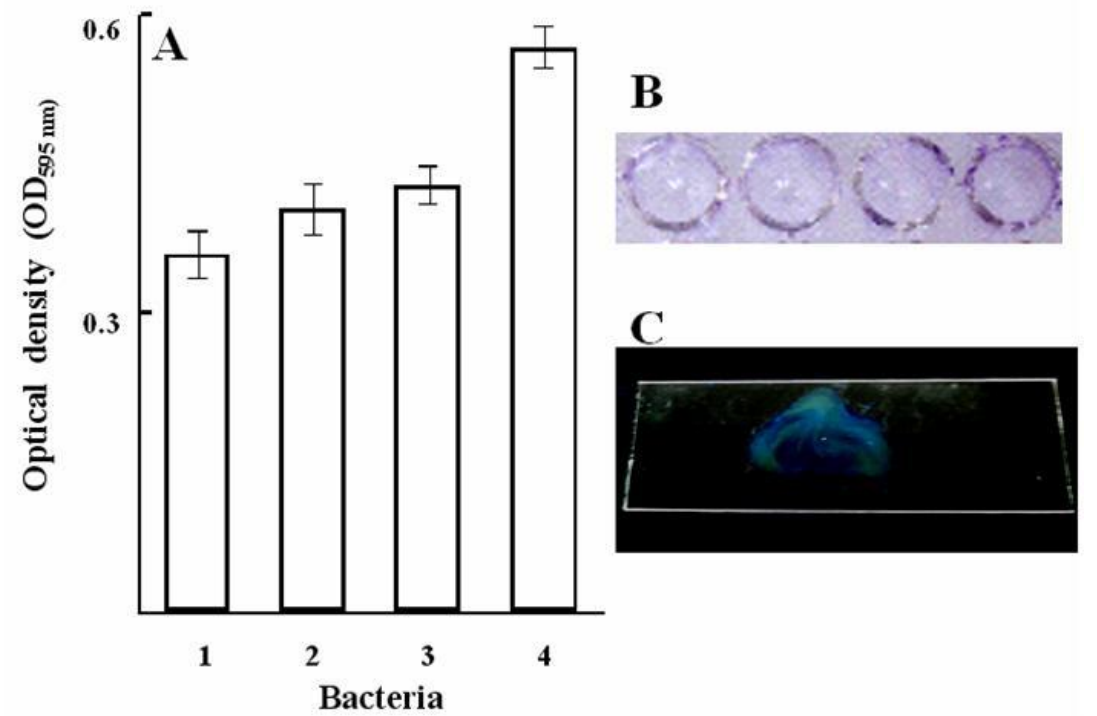

Fig1. The biofilm formation by bacteria isolated from water pipes. A. The biofilm was measured spectrophotometrically using violet crystal (1: E. coli; 2: P. aeruginosa; 3: K. oxytoca; 4: C. freundii). B. Staining the bacterial biofilm in plate wells. C. Confirming the presence of bacteria forming biofilm with calcofluor white staining

Table1. The resistance profile to antibiotics by bacteria forming biofilm in water pipes

\begin{tabular}{|l|l|l|l|l|l|l|}
\hline Bacteria & P & OX & TE & SXT & F & AK \\
\hline E. coli & $\mathrm{R}$ & $\mathrm{R}$ & $\mathrm{R}$ & $\mathrm{S}$ & $\mathrm{S}$ & $\mathrm{S}$ \\
\hline P. aeruginosa & $\mathrm{R}$ & $\mathrm{R}$ & $\mathrm{S}$ & $\mathrm{R}$ & $\mathrm{R}$ & $\mathrm{S}$ \\
\hline K. oxytoca & $\mathrm{R}$ & $\mathrm{R}$ & $\mathrm{S}$ & $\mathrm{S}$ & $\mathrm{S}$ & $\mathrm{S}$ \\
\hline C. freundii & $\mathrm{R}$ & $\mathrm{R}$ & $\mathrm{S}$ & $\mathrm{S}$ & $\mathrm{S}$ & $\mathrm{S}$ \\
\hline
\end{tabular}

$R, S$ - Resistant; Sensitive.

P- Penicillin, OX- Oxacillin, TE-Tetracycline, SXT- Trimethoprim/Sulfamethoxazole, F- Nitrofurantoin, AK-Amikacin.

\section{DisCUSSION}

The most bacteria are the environment forming biofilm (Costerton, 1999; Hall-Stoodley et al., 2008). It has been reported that the formation of bacterial biofilm contributes significantly to antibiotic resistance (Stewart and Costerton, 2001). The drinking water must be free of pathogenic infectious agents, however it has been observed that it has a variety of microorganisms, including bacteria forming biofilm in distribution systems (Wang et al., 2014).

In recent years, the growth of bacteria in water pipes has been of interest in many countries, especially since pathogenic bacteria can grow forming biofilms in them (Mahapatra et al., 2015). The formation of biofilm is a dynamic and continuous process that forms a complex microenvironment in the water pipes (Ashbolt, 2015; Hall-Stoodley et al., 2008; Nazar, 2007).

In a previous study we detected the presence of bacteria forming biofilm in water pipes (FloresEncarnación et al., 2016). This presence of bacteria forming biofilm in water pipes was in accordance with what was reported by other authors (Ashbolt, 2015; Hryniszyn et al., 2015; Knobelsdorf and Mujeriego, 1997; Mahapatra et al., 2015). From the bacteria recovered in the previous study, $P$. aeruginosa, E. coli, $C$. freundii and $K$. oxytoca were selected (because they were the most abundant bacteria in the water pipes) and biofilm formation was determinated. As was observed in Fig. 1, all bacteria formed biofilm and $C$. freundii showed the highest ability to form biofilm followed by $K$. oxytoca, $P$. aeruginosa and E. coli. The presence of bacteria forming biofilm was confirmed using staining of calcofluor white which binds to exopolysaccharides of biofilm matrix. It has been described that in water pipes bacteria can reproduce from the available organic matter. The factors that contribute significantly to the development of them are: ineffective concentration of disinfectants, $\mathrm{pH}$ and water temperature, residence time of the water in the tanks and piping, tube construction 
material. So the drinking water loses quality along its passage through the water supply pipes (Wang et al., 2014). The presence of bacteria in water pipes indicates the poor quality of water and water is a vehicle for diffusion of pathogenic bacteria (Chaves-Simões and Simões, 2013).

On the other hand, water distribution systems are places where bacteria remain viable for a long time; there bacteria can to exchange genetic material and it provides resistance to antibiotics (Armstrong et al., 1981; Li et al., 2015). In this context it has been common to find reports regarding the presence of antibiotics in wastewater, water from treatment plants or river water (Li et al., 2015; Martínez et al., 2010). However, in recent years it has been of interest to notice the presence of bacteria in drinking water pipes, especially bacteria that are resistant to different antibiotics. Thus in the present study, it was determined the antibiotic resistance profile by P. aeruginosa, E. coli, C. freundii and $K$. oxytoca which were isolated from water pipes. The results showed that those bacteria were resistant to penicillin and oxacillin (Table 1). Majority of them were found to be resistant to tetracycline (75\%) and were more susceptible to trimethoprim/sulfamethoxazole (75\%). All bacteria of this study were sensitive to amikacin. As it was expected, $P$. aeruginosa showed the maximum resistance found to group of antibiotics probed, however it was found more susceptible to tetracycline and amikacin. $E$. coli was found to be sensitive to trimethoprim/sulfamethoxazole, nitrofurantoin and amikacin and it showed resistance to penicillin, oxacillin and tetracycline. $K$. oxytoca and $C$. freundii were found to be more sensitive to tetracycline, trimethoprim/sulfamethoxazole, nitrofurantoin and amikacin and they showed resistance to penicillin and oxacillin. It has been described that biofilm gives the microcolonies a resistance mechanism to antibiotics, being extremely effective and conferring resistance to bacteria by a factor of about 500 times than usual (Bruce et al., 2007). The above data were of great interest since it is assumed that the water used daily should be free of pathogenic bacteria. However, the formation of biofilm inside the water pipes is indicative that there must be planktonic bacteria freely circulating in the water and that the formation of biofilm represents an important element for the survival of the bacteria adhered to the water pipes. The most surprising was to find pathogenic bacteria resistant to some antibiotics which could represent a possible risk to public health, especially for those immunocompromised individuals.

\section{CONCLUSION}

The biofilm formation is a advantage for bacteria. In addition to facilitating the intercellular communication within a biofilm, bacteria can survive when there is nutrient deficient conditions or when bacteria are found in dynamic environments. Also the biofilm formation provides the protection from antibiotics and disinfectants. It is important to understand how bacteria are capable of grow under low-nutrient conditions for long periods of time attached to pipe surfaces forming biofilm and the most relevant is that they are pathogenic bacteria resistant to antibiotics.

\section{ACKNOWLEDGEMENTS}

Thank to PRODEP and VIEP-BUAP for the facilities provied for the development of this work. Thank to Arturo Reyes-Pérez, Chemist pharmacobiologist, for their valuable technical support to carry out this work.

\section{REFERENCES}

[1] Anderl JN, Franklin MJ and Stewart PS (2000). Role of antibiotic penetration limitation in Klebsiella pneumoniae biofilm resistance to ampicillin and ciprofloxacin. Antimicrob. Agents Chemother. 44:1818-1824.

[2] Armstrong JL, Shigeno DS, Calomiris JJ and Seidler RJ (1981). Antibiotic-resistant bacteria in drinking water. Appl. Environ. Microbiol. 42:277-283.

[3] Ashbolt NJ (2015). Microbial contamination of drinking water and human health from community water systems. Curr. Environ. Health Rep. 5:95-106.

[4] Bridier A, Briandet R, Thomas V, Dubois-Brissonnet F (2011). Resistance of bacterial biofilms to disinfectants: a review. Biofouling. 27:1017-1032.

[5] Bruce D, Diamond JBH and Miranda NG (2007). Biofilm: Latent threat or protective factor? State of art. Enf. Inf. Microbiol. 27:22-28.

[6] Ceri H, Olson ME, Stemick C, Read RR, Mork D and Buret A (1999). The Calgary biofilm device: new technology for rapid determination of antibiotic susceptibilities of bacterial biofilms.

J. Clin. Microbiol. 37:1771-1776. 
[7] Chaves-Simões L and Simões M (2013). Biofilms in drinking water: problems and solutions. RSC Adv. 3:2520-2533.

[8] Costerton JW, Lewandoski DE, Cadwell DR, Corber HM and Lappin-Scott H (1995). Microbial biofilms. Annu. Rev. Microbiol. 49:711-745.

[9] Costerton JW (1999). Introduction to biofilms. Int. J. Antimicrob. Agents. 11:217-221.

[10] Decho AW (2013). The EPS matrix as an adaptive bastion for biofilms: Introduction to special issue. Int. J. Mol. Sci. 14:23297-23300.

[11] Donlan RM (2011). Biofilm elimination on intravascular catheters: important considerations for the infectious disease practitioner. Clin. Infect. Dis. 52:1038-1045.

[12] Flores-Encarnación M, Aguilar-Gutiérrez GR, Ixtepan-Tejero C, Juárez-Salazar G, MartínezVaquero JL, Cabrera-Maldonado C, Xicohténcatl-Palacios RC (2014). Biofilm: a natural mechanism of bacterial resistance. Inter. J. Curr. Res. 6:10420-10424.

[13] Flores-Encarnación M, Jaramillo-Rodríguez JB, Xicohténtal-Cortés J, Amador-Bravo D, Aguilar-Gutiérrez GR, Cabrera-Maldonado C, León-Tello G, Tagle-Ruíz A, García-López A, Meneses-Sánchez MC (2016). The presence of bacteria forming biofilm in water pipes commonly used at Puebla, México. Inter. J. Curr. Res. 8:25961-25965.

[14] Hall-Stoodley L, Costerton JW and Stoodley P (2008). Bacterial biofilms: from the natural environmental to infectious diseases. Nat. Rev. Microbiol. 2:95-108.

[15] Knobelsdorf J and Mujeriego R (1997). Crecimiento bacterino en las redes de agua potable: una revisión bibliográfica. Ing. Agua. 4:17-28.

[16] Kostakiotil M, Hadjifrangiskou M and Hultgren SJ (2013). Bacterial biofilms: development, dispersal, and therapeutic strategies in the dawn of the postantibiotic Era. Cold Spring Harb Perspect. Med. 3:a010306.

[17] Hryniszyn A, Cwalina B and Staszewski M (2015). Bacterial contribution to the deposits formation in steel water pipeline: x-ray diffraction study. CHEMIK. 69:586-591.

[18] Li J, Cheng W, Xu L, Strong PJ and Chen H (2015). Antibiotic-resistant genes and antibioticresistant bacteria in the effluent of urban residential areas, hospitals, and a municipal wastewater treatment plant system. Environ. Sci. Pollut Res. 22:4587-4596.

[19] Mahapatra A, Padhi N, Mahapatra D, Bhatt M, Sahoo D, Jena S, Dash D and Chayani N (2015). Study of biofilm in bacteria from water pipelines. J. Clin. Diag. Res. 9:9-11.

[20] Martínez A, Cruz M, Veranes O, Carballo ME, Salgado I, Olivares S, Lima L and Rodríguez D (2010). Resistencia a antibióticos y a metales pesados en bacterias aisladas del río Almendares. Rev. CENIC. Ciencias Biol. 41:1-10.

[21] Nazar JC (2007). Biofilms bacterianos. Rev. Otorrinolaringol. Cir. Cabeza Cuello. 67:61-72.

[22] Stepanovic S, Cirkovic I, Raning L and Svabic-Vlalhovic M (2004). Biofilm formation by Salmonella sp and Listeria monocytogenes on plastic surface. Lett. Appl. Microbiol. 38:428-432.

[23] Stewart PS and Costerton JW (2001). Antibiotic resistance of bacteria in biofilms. Lancet. 385:135-138.

[24] Wang H, Masters S, Edwards MA, Falkinham JO and Pruden A (2014). Effect of disinfectant, water age, and pipe materials on bacterial and eukaryotic community structure in drinking water biofilm. Environ. Sci. Technol. 48:1426-1435. 